Nalar: Jurnal Peradaban dan Pemikiran Islam

Vol. 2, No. 2, Desember 2018

\title{
Dakwah Di Kalangan Masyarakat Transmigran: Studi Terhadap Kompetensi Da'i Di Dusun Cilodang Kecamatan Pelepat Kabupaten Bungo Jambi
}

\author{
Ansori Hidayat \\ Sekolah Tinggi Agama Islam Yayasan Nurul Islam Muara Bungo, Jambi \\ andrejulie2@gmail.com
}

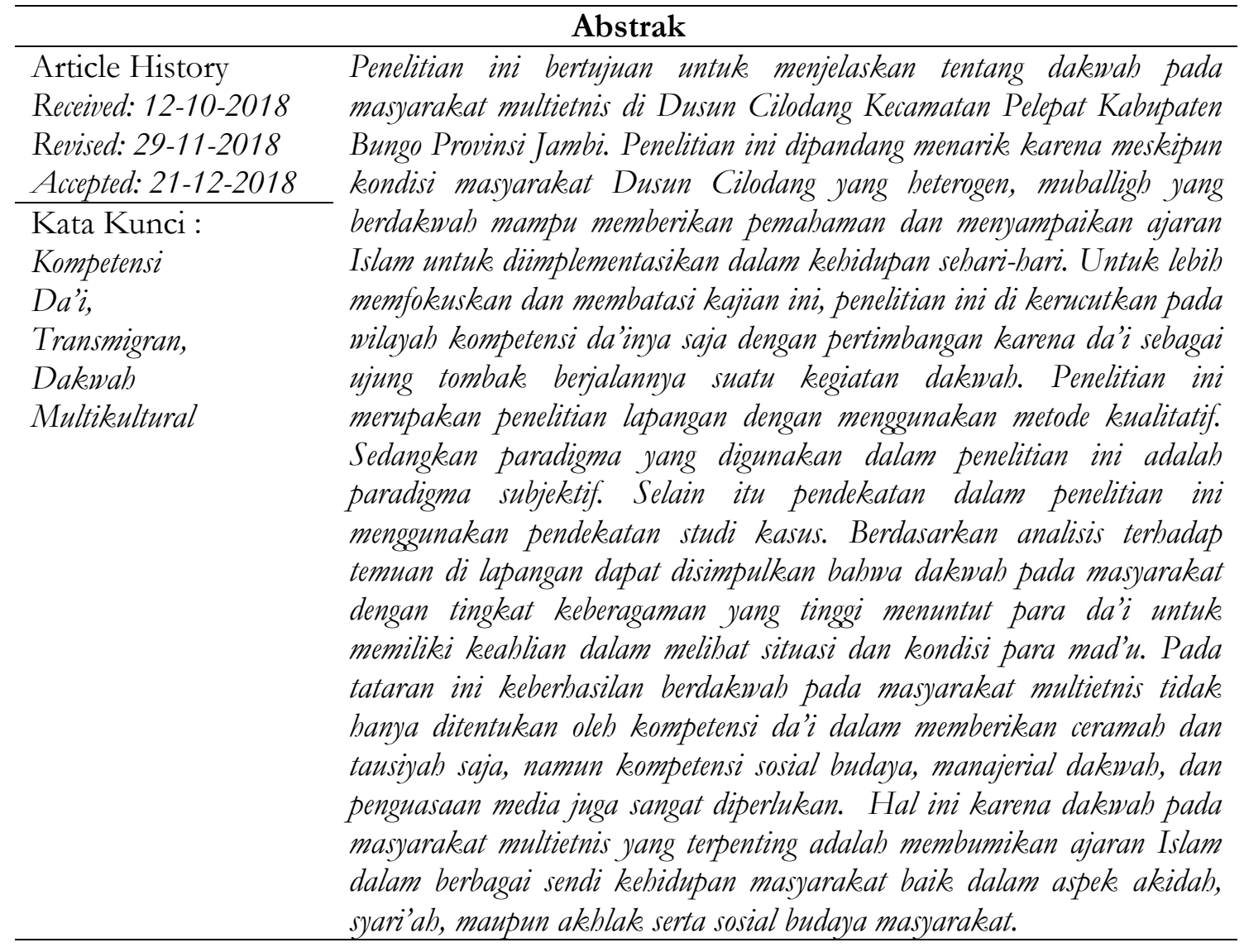

\section{Pendahuluan}

Kabupaten Bungo Provinsi Jambi merupakan kabupaten yang melaksanakan program transmigrasi dan menjadi tujuan transmigrasi. Program transmigrasi khususnya di kabupaten Bungo telah berlangsung sejak tahun 1982. Program transmigrasi ini berjalan sebagai bentuk dukungan pemerintah daerah kabupaten Bungo terhadap program pemerintah pusat dalam pemerataan pembangunan di seluruh penjuru Indonesia. Menurut Rukman Sardjadidjadja (2004:85), transmigrasi merupakan perpindahan penduduk dari suatu daerah yang padat penduduk ke daerah lain yang jarang penduduknya di wilayah Republik Indonesia (RI) untuk tinggal menetap dalam rangka pembentukan masyarakat baru serta untuk membangun daerah, baik daerah yang ditinggalkan maupun yang didatangi dalam rangka pembangunan nasional.

Daerah transmigrasi memang sengaja dibangun oleh pemerintah RI sebagai tempat pemukiman penduduk yang dipindahkan atau pindah dari suatu daerah yang telah ditetapkan oleh pemerintah, dengan tujuan meningkatkan kesejahteraan hidup masyarakat. 
Nalar: Jurnal Peradaban dan Pemikiran Islam

Vol. 2, No. 2, Desember 2018

Penduduk yang bermukim disana berasal dari berbagai daerah yang datang dengan harapan akan memperoleh kehidupan yang lebih baik, sehingga banyak bermunculan anggapananggapan yang mengatakan bahwa orang-orang yang mengikuti transmigrasi atau biasa disebut orang trans adalah orang buangan dari daerah asalnya, atau yang lebih menyakitkan lagi adalah orang yang melarikan diri dari daerah asalnya karena tidak bisa mendapatkan kehidupan yang layak.

Transmigrasi di kabupaten Bungo dalam pelaksanaanya di bagi menjadi dua gelombang. Pertama, transmigrasi yang merupakan program pemerintah pusat atau transmigrasi umum. Pada program transmigrasi ini mereka yang mengikuti transmigrasi berasal dari luar provinsi Jambi yaitu Jawa Barat, Jawa Tengah dan Jawa Timur. Kedua, transmigrasi lokal. Peserta pada program transmigrasi ini yaitu mereka yang berasal dari kabupaten Bungo sendiri maupun dari wilayah provinsi Jambi.

Transmigrasi di kabupaten Bungo ditempatkan dalam satu wilayah yang di beri nama Kuamang Kuning. Kuamang Kuning merupakan daerah khusus transmigrasi yang terdiri dari dua puluh unit, satu unit terdiri dari satu desa. Secara geografis, wilayah transmigrasi Kuamang Kuning terbagi dalam tiga kecamatan, yaitu kecamatan Pelepat, kecamatan Pelepat Ilir dan kecamatan Merangin.

Dusun Cilodang kecamatan Pelepat kabupaten Bungo provinsi Jambi adalah salah satu desa yang berada di wilayah transmigrasi Kuamang Kuning. Dusun merupakan wilayah setingkat desa di kabupaten Bungo, provinsi Jambi. Hal ini sesuai dengan peraturan daerah kabupaten Bungo nomor 9 tahun 2007 yang menetapkan penyebutan kepala desa menjadi Rio, desa menjadi dusun dan dusun menjadi kampung. Penduduk desa Cilodang terbilang cukup beragam. Jika di desa tujuan transmigrasi lainya mereka datang dan berkumpul sesuai daerah asalnya, maka di dusun Cilodang ini terkumpul masyarakat dari berbagai asal diantaranya Jawa Barat, Jawa Timur dan Jawa Tengah. Periode pertama kedatangan transmigrasi pertama ke desa ini berasal dari pulau Jawa, selanjutnya transmigrasi lokal dari pulau Sumatera itu sendiri.

Masyarakat transmigran merupakan masyarakat yang memiliki karakteristik yang berbeda. Ia datang dari latar belakang sosial, ekonomi dan budaya yang berbeda yang membuat mereka harus berjiwa besar untuk menerima perbedaan yang ada dan menyesuaikan dengan segala macam hal baru. Dapat kita perhatikan, dalam satu suku saja terdapat perbedaan didalamnya. Sebagai suatu contoh, suku Sunda Majalengka dan Sunda Sumedang terdapat perbedaan dari sudut budaya maupun bahasanya.

Kehidupan baru di daerah transmigrasi setidaknya membawa dampak positif dan negatif. Dengan adanya transmigrasi, lahan-lahan kosong yang masih luas dapat dimanfaatkan, meningkatnya hasil produksi dalam bidang pertanian dan mempercepat pemerataan penduduk. Namun, kedatangan transmigran pada daerah ini tidak jarang menjadi konflik dengan kaum pribumi yang merasa terganggu dan tersaingi. Pertemuan berbagai macam etnis yang memiliki perbedaan tata bahasa, mengakibatkan sulitnya proses komunikasi. Belum lagi benturan-benturan ekonomi, sosial, agama, terutama benturan budaya yang menimbulkan suasana yang tidak harmonis turut mewarnai kehidupan para transmigran.

Dusun Cilodang didalamnya terdapat beberapa suku diantaranya Jawa, Sunda, Minang, Batak dan suku Melayu. Hal tersebut menjadikan dusun Cilodang sebagai sebuah dusun yang multietnik dan beragam dalam kehidupan sosialnya, keberagaman ini tentu berimbas pada tataran kehidupan sehari-hari seperti pertukaran bahasa, akulturasi budaya maupun kegiatan beragama. 
Nalar: Jurnal Peradaban dan Pemikiran Islam

Vol. 2, No. 2, Desember 2018

Karakter masyarakat yang beragam dan berasal dari tempat yang beragam memberikan implikasi yang berbeda pula pada pola pembinaan keagamaan dalam konteks dakwah yang dilaksanakan. Perbedaan ini paling tidak dapat dilihat dari aspek materi, metode maupun media. Menurut Enjang (2009:5), dakwah merupakan kegiatan mengajak kepada jalan Allah Swt. secara menyeluruh baik dengan lisan, tulisan maupun dengan perbuatan sebagai ikhtiar (upaya) muslim mewujudkan nilai-nilai ajaran Islam dalam realitas kehidupan pribadi (syahsiyah), keluarga (usrab), dan masyarakat (jama'ab) dalam semua segi kehidupan secara menyeluruh sehingga terwujud khairul ummah (masyarakat madani).

Dakwah dalam prosesnya akan melibatkan unsur-unsur (rukun) dakwah yang terbentuk secara sistemik. Dengan kata lain antara unsur yang satu dengan unsur lainya saling berkaitan. Unsur dakwah artinya sebagai elemen yang mesti ada dalam proses dakwah. Unsur dakwah tersebut meliputi da'i, maudhu, uslub, washilah dan mad'u. Dalam fenomena dakwah pada masyarakat multietnik seperti masyarakat transmigrasi, seorang da'i tentu memiliki beberapa hal yang dianggap berbeda dengan dakwah pada masyarakat yang relatif homogen.

Berlatar belakang dari fakta tersebut, menarik dan penting untuk dilakukan sebuah penelitian ilmiah tentang kompetensi dakwah da'i di lingkungan masyarakat transmigran sebagai masyarakat yang multietnik. Ketertarikan penelitian ini didasarkan pada beberapa pertimbangan. Pertama, pada masyarakat yang multikultural kompetensi yang dimiliki oleh seorang da'i memainkan peranan yang sangat penting agar dakwah yang dilakukan bisa diterima dengan baik oleh masyarakat secara keseluruhan. Kedua, program transmigrasi merupakan salah satu program pemerintah yang terus menerus dilaksanakan sebagai media pemerataan pembangunan pusat dan daerah, sehingga masyarakat transmigran akan terus bertambah. Pada tataran ini pembinaan terhadap masyarakat transmigran tidak hanya dilakukan dengan pembinaan ekonomi, tetapi juga melalui pendekatan dakwah. Ketiga, penelitian ini dapat digunakan untuk kepentingan bagaimana pembinaan pemberdayaan masyarakat melalui pendekatan agama, dengan kata lain agama sebagai salah satu unsur pembangunan.

Penelitian ini bertujuan untuk menjelaskan tentang dakwah pada masyarakat multietnis di Dusun Cilodang Kecamatan Pelepat Kabupaten Bungo Provinsi Jambi. Untuk lebih memfokuskan dan membatasi kajian ini, penelitian ini dikerucutkan pada wilayah kompetensi da'inya saja dengan pertimbangan karena da'i sebagai ujung tombak berjalannya suatu kegiatan dakwah. Da'i memiliki peranan yang sangat penting dalam pola kehidupan beragama masyarakat transmigran.

Penelitian ini merupakan penelitian lapangan dengan menggunakan metode kualitatif. Sedangkan paradigma yang digunakan dalam penelitian ini adalah paradigma subjektif. Secara subjektif, perilaku manusia dipahami dari sudut pandang dirinya, dengan kerangka pengalaman secara penuh dari individu itu sendiri. Temuan kemudian dirangkai dan dibuat struktur pengalaman itu untuk temuan-temuan ilmiah dan pemecahan masalah masyarakat yang dihadapi. Selain itu pendekatan dalam penelitian ini menggunakan pendekatan studi kasus. Melalui pendekatan ini, data akan digali dari pengalaman subjek kemudian kemudian digambarkan pemaknaan dari subjek tersebut kedalam bahasa tulisan.

\section{Kompetensi Da'i Dalam Berdakwah Kepada Masyarakat}

Dakwah merupakan amanah Allah Swt. yang dibebankan kepada hamba-Nya untuk menegakkan agama Islam. Dakwah adalah tanggung jawab setiap muslim untuk melaksanakan amar makruf dan nahi munkar. Perintah dakwah ditetapkan seiring dengan diturunkanya risalah kenabian kepada Muhammad saw. Risalah ini hadir melalui alquran 
Nalar: Jurnal Peradaban dan Pemikiran Islam

Vol. 2, No. 2, Desember 2018

sebagai manifestasi kalam Allah Swt. yang menuntun dan membawa umat manusia dari kegelapan menuju cahaya terang benderang. Dakwah merupakan ajakan, seruan, panggilan sekaligus do'a. Didalamnya terkandung dua kewajiban utama, yakni kewajiban teologis dan kewajiban sosiologis.

Pada sisi teologis, dakwah dipandang sebagai tugas spiritual untuk mengajak manusia kejalan ilahiah yakni al-Islam. Pada sisi ini pula dakwah dimaknai sebagai amanah yang berorientasi pada perwujudan kehidupan masyarakat yang didasarkan pada ajaran Islam. Sementara itu, pada sisi sosiologis, dakwah dipandang sebagai aktivitas muslim yang berorientasi pada perubahan. Dakwah sebagai kewajiban setiap muslim untuk menyeru pada jalan kebaikan. Perubahan sosial yang dikehendaki adalah sebuah desain peradaban yang didalamnya sarat dengan aspek akhlak (moralitas), uswah (keteladanan), dan bikmah (intelektualitas). Hal ini sebagai mana yang dicontohkan oleh Rasulullah saw. ketika menyampaikan risalah Islam pada umat manusia baik semasa di Makkah maupun di Madinah.

Aziz (2012:19) memberikan definisi dakwah sebagai kegiatan peningkatan iman menurut syariat Islam. Dakwah merupakan proses peningkatan iman dalam diri manusia sesuai syariat Islam. Proses menunjukan kegiatan yang terus menerus, berkesinambungan dan bertahap. Peningkatan adalah perubahan kualitas yang positif: dari buruk menjadi baik, atau dari baik menjadi lebih baik. Peningkatan iman termanifestasi dalam peningkatan pemahaman, kesadaran dan perbuatan. Untuk membedakan dengan pengertian dakwah secara umum, syariat Islam menjadi tolak ukur dakwah Islam. Dengan syariat Islam sebagai pijakan, hal-hal yang terkait dengan dakwah tidak boleh bertentangan dengan alquran dan hadis.

Dakwah pada hakekatnya adalah aktivitas dan kegiatan yang mengajak manusia untuk melakukan perubahan sesuai dengan tuntunan dan petunjuk dari Allah Swt. Pada tataran praktiknya dakwah dirumuskan sebagai proses internalisasi (pedalaman pemahaman ajaran Islam), transmisi (penyampaian ajaran Islam), difusi (penetrasi atau penanaman ajaran Islam), transformasi (perubahan atau pengkondisian ajaran Islam), dan aktualisasi (implementasi atau pelaksanaan ajaran Islam). Dakwah pada pelaksanaanya melibatkan unsur-unsur dari kegiatan dakwah yakni da'i (subjek), maudhu (pesan/materi), uslub (tatacara/metode), washilah (media/sarana) dan mad'u (objek).

$D a^{\prime} i$ adalah seseorang yang melaksanakan dakwah. Da'i merupakan ujung tombak bagi terlaksananya kegiatan dakwah. Da'i memiliki peranan penting bagi keberlangsungan syiar Islam dan kehidupan beragama masyarakat. Da'i ibarat seorang guide atau pemandu terhadap orang-orang yang ingin mendapatkan keselamatan hidup di dunia dan akhirat. Da'i memiliki peran untuk memberikan petunjuk jalan yang harus dimengerti dan dipahami. Jalan yang boleh dilalui dan yang tidak boleh dilalui oleh seorang muslim. Oleh karena itu, di tengah masyarakat da'i memiliki kedudukan yang penting sebagai seorang pemuka (pelopor) yang selalu diteladani oleh masyarakat. Perbuatan dan tingkah lakunya selalu dijadikan tolak ukur oleh masyarakatnya. Da’i juga seringkali berperan sebagai seorang pemimpin di tengah masyarakat walau tidak pernah dinobatkan resmi sebagai pemimpin. Dalam konteks ini Amin (2009:69) memandang bahwa kemunculan da'i sebagai pemimpin adalah atas pengakuan masyarakat yang tumbuh secara bertahap. Dalam proses pelaksanaanya, seorang da'i secara tidak langsung dituntut untuk memiliki kompetensi sebagai penunjang keberhasilannya dalam berdakwah.

Kompetensi adalah suatu hal yang dikaitkan dengan kemampuan, pengetahuan/wawasan, dan sikap yang dijadikan suatu pedoman dalam melakukan tanggung jawab pekerjaan yang dikerjakan. Dakwah sebagai suatu kegiatan melibatkan 
Nalar: Jurnal Peradaban dan Pemikiran Islam

Vol. 2, No. 2, Desember 2018

unsur-unsur seperti da'i, metode, materi dan media dakwah. Da’i sebagai instrumen pokok dakwah pada kegiatannya perlu di tunjang oleh kompetensi demi tercapainya tujuan dakwah.

Temuan di lapangan menunjukkan bahwa kompetensi da'i secara umum dalam berdakwah terhadap masyarakat transmigran di Dusun Cilodang terbagi menjadi empat yaitu kompetensi keilmuan, kompetensi metode dakwah, kompetensi penguasaan materi, dan kompetensi penguasaan media dakwah.

\section{Kompetensi Keilmuan untuk Berdakwah Pada Masyarakat Transmigran}

Kompetensi pertama yang dimiliki däi di Dusun Cilodang adalah kompetensi keilmuan. Kompetensi ini terkait dengan wawasan tentang keragaman budaya, kesiapan mental, kesiapan fisik dan kemampuan mengelola lembaga pendidikan. Kompetensi keilmuan merupakan satu hal yang mutlak harus dimiliki oleh seorang da'i dimanapun. Keilmuan yang mesti dimiliki tersebut setidaknya bisa diuraikan pada dua masalah pokok yaitu ilmu sebagai materi atau bekal untuk disampaikan dan ilmu sebagai penunjang pada proses tercapainya pesan dakwah dari da'i kepada mad'u. Ilmu sebagai materi dakwah adalah segala sesuatu yang bersumber dari alquran dan sunnah Rasulullah saw. Ilmu sebagai materi atau pesan dakwah secara umum dapat dikategorikan pada masalah aqidah, syariah dan akhlak.

Menurut Asmuni Syukir (2004:44), pada dasarnya materi dakwah Islam tergantung pada tujuan dakwah yang hendak dicapai. Namun secara global dapat dikatakan bahwa materi dakwah dapat diklasifikasikan pada tiga hal pokok yaitu aqidah, syariah dan akblak. Secara etimologis, kata aqidah berarti "ikatan", sedangkan secara teknis, aqidah dapat diartikan iman, kepercayaan, atau keyakinan. Iman adalah suatu jaminan guna menghadapi ketakutan dan kekecewaan dalam lika-liku kehidupan. Aqidah adalah pondasi dari ajaran Islam. Menurut Harun Nasution (1995:347), aqidah lahir dari ajaran paling dasar dalam Islam, yakni keimanan. Dengan kata lain, pembahasan berkenaan dengan aqidah pada umumnya berbicara tentang rukun iman yang enam, yakni iman kepada Allah, iman kepada malaikat, iman kepada kitab-kitab Allah, iman kepada para Nabi Allah, Iman kepada hari kiamat, serta iman kepada qada dan qadar (Anshari, 2004:44).

Materi dakwah kedua adalah syariah. Secara etimologi syariah berarti “jalan”. Syariat Islam merupakan suatu norma Ilahi yang mengatur hubungan antara manusia dengan Tuhan, manusia dengan manusia, dan manusia dengan alam. Lebih jauh Muhammad Hashim Kamali (2013:5) berpendapat bahwa, syariat adalah jalan menuju agama, yang didalamnya meliputi nilai-nilai yang esensial bagi Islam. Sejatinya syariah terbagi kedalam dua bagian, yakni 'ubudiyah dan mu'amalah. Dalam bagian 'ubudiyah (ibadah), terkenal lima pilar yang akrab disebut rukun Islam, yakni syahadat, shalat, puasa, zakat, dan haji. Kelima pilar tersebut merupakan bagian pokok dalam kegiatan ibadah kepada Tuhan (bablu min Allah).

Sedangkan dalam bagian mu'amalah (transaksi sipil), norma Ilahi mengatur hubungan antara manusia dengan manusia dan manusia dengan alam. Mu'amalah dalam arti luas terbagi pula kedalam dua bagian besar, pertama, al-qanun al-khas (hukum perdata) yang meliputi perdagangan, pernikahan (munakahat), warisan (warasat), dan sebagainya. Sedangkan bagian yang kedua, al-qanun al-am (hukum publik) yang meliputi hukum pidana (jinayah), hukum kenegaraan (khilafah), dan lain sebagainya.

Materi dakwah yang ketiga yaitu akhlak. Secara etimologis, akhlak dapat diartikan perbuatan, perangai, tabiat, atau kebiasaan. Pembinaan akhlak yang baik adalah salah satu pokok dari ajaran Islam. Akhlak dalam ajaran Islam tidak dapat disamakan dengan etika. 
Nalar: Jurnal Peradaban dan Pemikiran Islam

Vol. 2, No. 2, Desember 2018

Dalam pandangan Quraish Shihab (2004:261) jika etika hanya diartikan sebagai perilaku sopan santun antar sesama manusia dan hanya berkaitan pada perilaku lahiriyah saja, maka akhlak jauh lebih luas dari pada itu. Akhlak juga berkaitan dengan hal-hal yang bukan merupakan sifat lahiriyah. Seperti yang berkaitan dengan sifat-sifat batiniyah atau pikiran. Setidaknya akhlak menyangkut tiga aspek, yakni hablu min Allah (hubungan antara manusia dengan Tuhan) bablu min al-nas (hubungan antar sesama manusia) dan bablu min al-'alam (hubungan manusia dengan alam).

Selain keilmuan pokok sebagai bekal untuk disampaikan kepada mad'u, di perlukan juga ilmu lainnya sebagai penunjang atau sebagai ilmu yang membantu tercapainya tujuan dakwah. Salah satu ilmu bantu yang harus dimiliki adalah ilmu sosial. Ilmu sosial tersebut yaitu ilmu yang mempelajari tentang seluk beluk dan bagaimana manusia berinteraksi. Sebagai ilmu bantu, da'i tidak harus menguasai keseluruhan dari keilmuan tersebut secara teoritis. Da'i hanya dituntut untuk mengetahui bagaimana situasi dan kondisi khalayak yang akan ia dakwahi.

Keilmuan lain yang dapat membantu efektivitas dakwah juga disinggung oleh Samsul Munir Amin (2009:81), menurutnya keanekaragaman pengetahuan dan pendidikan anggota masyarakat menuntut da'i membekali dirinya dengan seperangkat pengetahuan yang dapat menjadikan da'i tidak ketinggalan informasi dibanding anggota masyarakatnya. Sedangkan menurut Ali Aziz (2012:71) ilmu bantu untuk ilmu dakwah salah satunya sains sosial. Sains sosial menerangkan berbagai macam segi kehidupan individu dan masyarakat secara detail dan terperinci. Pada tataran ini sebagai seseorang yang senantiasa berhadapan langsung dengan kondisi masyarakat yang heterogen, da'i pada masyarakat multikultural di Dusun Cilodong harus mempelajari berbagai gejala sosial yang ada. Pertikaian antar-etnik merupakan hal yang lazim terdengar di telinga masyarakat. Oleh karena hal tersebut, sebisa mungkin bagi da'i ikut mengamati kemudian mencari solusi sebaik mungkin akan berbagai persoalan masyarakat tersebut.

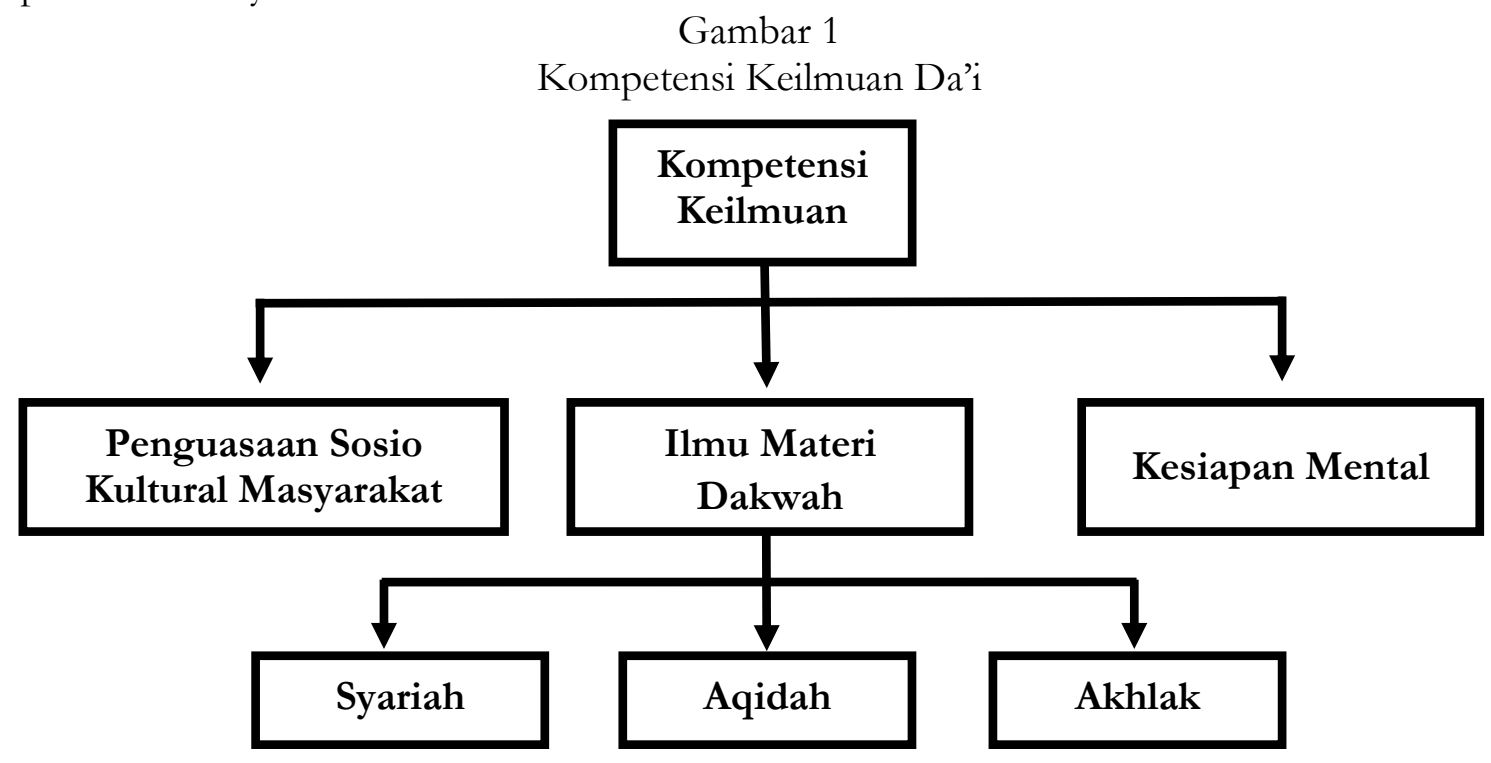

\section{Kompetensi Da'i Terkait Metode Dakwah Pada Masyarakat Transmigran}

Sebagaimana masyarakat pada umumnya, masyarakat transmigran adalah salah satu sasaran dakwah Islam. Kelompok masyarakat ini merupakan yang berada dalam satu wilayah yang tergolong pada masyarakat pedesaan. Hanya saja, terdapat perbedaan yang signifikan dengan masyarakat pedesaan pada umumnya, masyarakat transmigran ini 
Nalar: Jurnal Peradaban dan Pemikiran Islam

Vol. 2, No. 2, Desember 2018

memiliki tingkat keragaman yang tinggi berdasarkan etnik dalam keanggotaan masyarakatnya.

Berdasarkan pemaparan hasil observasi lapangan dan hasil wawancara dengan para $d a^{\prime} i$, pola penyampaian pesan dakwah oleh para $d a^{\prime} i$ di Dusun Cilodang didominasi dengan ceramah keagamaan. Meskipun demikian ada beberapa metode lain seperti pengelolaan lembaga pendidikan Islam dan organisasi keislaman, keteladanan dan nasehat bagi para jama'ah yang sedang memiliki masalah. Kegiatan ceramah keagamaan di Dusun Cilodang ini didominasi dengan berbagai pengajian baik itu pengajian ibu-ibu maupun bapak-bapak yang bertempat di rumah-rumah warga. Pengajian ini bergantian dari rumah ke rumah lainya dalam waktu seminggu sekali. Untuk pengajian ibu-ibu dilaksanakan $b a^{\prime} d a$ ashar dan pengajian bapak-bapak $b a^{\prime} d a$ magrib. Konten dari pengajian ini diawali dengan membaca alquran bersama-sama, setelah itu masuk pada inti pengajian yaitu tausiyah atau ceramah dari ustad yang bertugas.

Ceramah dalam pandangan Amin (2009:101) adalah metode yang dilakukan dengan maksud untuk menyampaikan keterangan, petunjuk, pengertian, dan penjelasan tentang sesuatu kepada pendengar dengan menggunakan lisan. Pada umumnya, kegiatan ceramah seringkali diarahkan kepada publik (kelompok masyarakat), bukan kepada individu saja. Maka dari itu, metode ini juga seringkali dikaitkan dengan publick speaking, karena samasama menuntut seseorang untuk berbicara dihadapan publik. Metode dakwah seringkali atau bahkan selalu menggunakan komunikasi satu arah (monolog) dari seorang da'i kepada mad'u. Pesan-pesan dakwahnya pun biasanya hanya bersifat ringan namun tetap informatif, karena pesan dakwah yang disampaikan dengan metode ini harus langsung bisa dipahami oleh mad'u (Aziz, 2012: 359).

Metode ceramah hingga saat ini masih menjadi salah satu metode dakwah yang paling populer serta paling digemari. Begitu populernya, metode ceramah ini bahkan seringkali dijadikan sebagai konotasi dari kegiatan dakwah. Dewasa ini, masyarakat menganggap bahwa dakwah adalah ceramah, ceramah adalah dakwah, jika bukan ceramah maka itu bukan dakwah. Padahal jika diteliti, ceramah hanyalah merupakan salah satu metode dalam sebuah kegiatan dakwah yang amat sangat luas.

Agar kegiatan ceramah mampu menarik minat masyarakat, salah satu yang harus ada dalam ceramah keagamaan di Dusun Cilodang adalah dengan diselingi oleh humorhumor segar. Aspek humor dalam diri seorang da'i pun dapat dilihat dari bagaimana panitia tablig akbar Dusun Cilodang dalam memilih penceramah. Salah satu hal yang diperhatikan dalam pemilihan penceramah tersebut selain keilmuanya yaitu da'i yang memiliki selera humor.

Penyisipan humor dalam ceramah para da'i di Dusun Cilodang memiliki beberapa alasan diantaranya untuk lebih mengakrabkan diri, menyegarkan situasi, ataupun sebagai media penjelasan materi melalui humor tersebut. Penyisipan humor dalam ceramah menurut para da'i sudah berlangsung cukup lama atau semenjak adanya masyarakat baru bertransmigrasi. Tidak dapat dipungkiri, kegiatan keagamaan seperti tahlilan, marhabaan, maulid nabi sarat akan nilai-nilai silaturahmi sehingga memudahkan antar sesama saling mengenal dan berinteraksi.

Aang Ridwan (2010:949) memandang bahwa humor dalam ceramah merupakan standar etis suatu ceramah. Humor yang bisa disisipkan dalam tablig adalah humor yang setidakanya memiliki empat kriteria. Pertama, kriteria edukasi, yakni humor yang memiliki kandungan pesan mendidik dan membawa misi pencerahan. Humor jenis ini tidak hanya membawa misi rekreatif tetapi juga membawa misi mencerdaskan. Kedua, humor yang memiliki kriteria kritis yakni humor yang bisa menstimulus mad'u untuk melakukan analisis 
Nalar: Jurnal Peradaban dan Pemikiran Islam

Vol. 2, No. 2, Desember 2018

atas sejumlah diesequiblirium atau ketimpangan dan ketidakseimbangan realitas kehidupan. Dalam pembahasan terdahulu telah disebutkan bahwa diantara fungsi humor adalah sebagai media kritik sosial. Dalam fungsi ini humor akan menggerakan kesadaran mad'u untuk melihat apakah harmoni atau disharmoni antara das sein dan das solen. Ketiga, tidak rasis yakni humor yang tidak berisi hinaan, penodaan, dan citraan stigmatis atas seseorang, lembaga, agama, ras atau golongan. Humor jenis ini terkategori humor fasid, rusak. Disebut demikian karena humor dalam kriterium ini selain tidak berisi ibrah yang bisa menuntun mad'u untuk berbuat baik juga telah terbukti dapat memicu lahirnya perilaku konfliktual. Humor jenis ini memang kaya dengan muatan-muatan komedian dan unsur komikal lainnya yang bisa mengundang gelak tawa, namun sesungguhnya kosong dari muatan-muatan positif dan konstruktif. Keempat, tidak pornografis yakni humor yang tidak mengeksploitasi tubuh dan sensasional badaniyah melalui pembicaraan jorok dan porno. Humor kategori ini jumlahnya sangat banyak. Tentu saja banyaknya jumlah humor jenis ini dikarenakan banyak user yang menggemari. Sama seperti humor rasis, humor pornografis sangat banyak genre-nya dan ditampilkan dalam banyak ragam produk komunikasi.

Fenomena penyisipan humor dalam ceramah keagamaan memang sesuatu hal yang terkadang diperlukan. Sebagian masyarakat bahkan meminta pada para muballig untuk berceramah dengan diselingi humor dengan berbagai alasan. Bahkan ada pula sebagian yang menganggap bahwa ceramah agama identik dengan ceramah yang diselingi humor. Meskipun demikian, beberapa ketentuan yang mesti diperhatikan adalah esensi dakwah itu sendiri. Tentu saja seorang däi harus selalu konsisten dengan tujuan awalnya yaitu menyampaikan ajaran Islam kepada mad'u. Selain kemampuan berceramah diatas, seorang da'i pada masyarakat transmigran juga dituntut untuk mampu mengembangkan atau mengelola lembaga pendidikan Islam seperti madrasah diniyah. Hal ini cukup relevan mengingat lembaga pendidikan terkadang luput dari perhatian para tokoh agama. Selama ini konsentrasi dakwah maupun tabligh hanya pada pengajian-pengajian dengan ceramah sebagai metode dakwahnya.

Pengelolaan lembaga pendidikan Islam dalam ilmu dakwah dikenal dengan metode kelembagaan. Metode kelembagaan juga merupakan bagian dari bentuk dakwah bi al-hal. Metode ini merupakan aktivitas pelestarian nilai dan norma dalam wadah organisasi yang bertindak sebagai instrumen dakwah (Aziz, 2012:381). Dakwah bi al-hal adalah bentuk ajakan kepada Islam dalam bentuk amal, kerja nyata, baik yang sifatnya mendirikan lembaga pendidikan Islam, kerja bakti, mendirikan bangunan keagamaan dan hal lainnya (Amin, 2009:178).

Lembaga pendidikan Islam seperti madrasah diniyah sejatinya merupakan lembaga dakwah. Meskipun tidak mengandung istilah dakwah didalamnya, namun pada prosesnya memiliki kesamaan dengan dakwah yaitu pentransmisian ajaran Islam dari guru kepada murid. Pandangan masyarakat pun cenderung menganggap bahwa lembaga pendidikan Islam seperti madrasah diniyah tidak lebih dari lembaga pendidikan biasa seperti pada umumnya.

Penguatan kompetensi da'i melalui metode kelembagaan dalam madrasah diniyah dapat disandarkan pada beberapa alasan di antaranya, anak-anak yang masih berusia sangat muda dapat menjadi penerus bagi para da'i dalam mengajarkan ilmu agama, sebagai bentuk kaderisasi da'i agar kelangsungan dakwah tidak terputus hanya karena tidak adanya sumber daya manusia.

Kompetensi terkait metode selanjutnya yaitu kompetensi dalam mengelola organisasi keislaman. Salah satu yang terus dibina dan dikembangkan oleh para da'i adalah ikatan remaja masjid atau IRMA. Pengembangan ikatan remaja mesjid ini sebagai tindak 
Nalar: Jurnal Peradaban dan Pemikiran Islam

Vol. 2, No. 2, Desember 2018

lanjut dari tidak adanya kegiatan keagamaan bagi para remaja selepas menyelesaikan madrasah diniyah.

Pembinaan remaja masjid di Dusun Cilodang ini terbilang cukup baru. Gagasan tentang perlunya menghimpun para remaja yang tidak memiliki kegiatan selepas menyelesaikan madrasah diniyah ini dicetuskan oleh Ustad Anang Hikman. Dalam pelaksanaan dan pengawasannya, seluruh elemen masyarakat dari mulai pemerintah sampai tokoh agama juga turut dilibatkan. Pertimbangan lain dari penggagasan inipun terbilang penting yaitu agar tidak terputusnya pendidikan Islam bagi para generasi muda.

Menurut Hajir Tajiri (2015:83), pengelolaan organisasi Islam semacam ini dalam teori dakwah dikenal dengan kompetensi muthwir yaitu mampu melebur dalam pergaulan di tengah masyarakat, mampu membaca kebutuhan masyarakat, mampu membuat konsep pemecahan atas persoalan yang berkembang di masyarakat, mampu mempertahankan karakter positif dan kredibilitas di tengah masyarakat. Kondisi tersebut menuntut tangantangan terampil dan profesional dalam pengembangan masyarakat Islam atau pemberdayaan masyarakat. Keahlian dalam pemberdayaan masyarakat memang salah satu hal yang harus dimiliki oleh para $d a^{\prime} i$. Dakwah sejatinya tidak melulu pada proses penyampaian pesan-pesan dakwah saja, melainkan seorang da'i dituntut untuk menjadi solusi bagi berbagai persoalan yang ada dalam masyarakat. Paradigma da'i dalam berdakwah sudah selayaknya lebih maju menjadi dakwah yang solutif. Menjadi agen perubahan sosial masyarakat menjadi lebih baik.

Selanjutnya bagi seorang da'i pada masyarakat transmigran memerlukan keahlian dalam memadukan antara ucapan dan perbuatan. Keterangan dari seluruh informan dalam penelitian di Dusun Cilodang ini menekan bahwa dakwah pada masyarakat transmigran adalah perlunya sinkronisasi antara ucapan dan perbuatan. Hal ini tidak terlepas dari fakta bahwa masyarakat menjadikan $d a^{\prime} i$ sebagai contoh baik itu perkataanya maupun perbuatannya.

Sebagaimana yang diterangkan Ibnu al-Munir yang dikutip Rukhaeni (2016: 159) bahwa yang dikehendaki adalah ilmu itu syarat sahnya ucapan dan perbuatan. Dengan kata lain, setiap amal ucapan dan perbuatan harus dilakukan dengan dasar dan landasan ilmu pengetahuan. Oleh karena itu setiap da'i yang akan berkata dan berbuat wajib baginya untuk mengetahui seluk beluk permasalahan tersebut serta tidak dibenarkan pula melakukan suatu hal yang ia tidak memiliki pengetahuan tentangnya. Merujuk pendapat Munir tersebut, seorang pendakwah tidak hanya dituntut untuk memiliki akhlak yang baik serta mampu memberi teladan, namun juga mempunyai kewajiban untuk mendalami dan menguasai ilmu yang akan ia dakwahkan. Hal tersebut menjadi kewajiban karena apa yang akan ia ajarkan menjadi pedoman atau acuan bagi orang lain. Sehingga apabila yang ia ajarkan benar maka mad'u akan melaksanakan yang benar begitu pula sebaliknya apabila yang diajarkan salah maka mad'u akan melakukan hal yang salah.

Perkataan dan perbuatan seorang da'i harus sesuai antara ucapan dan perbuatanya. Oleh karenanya seorang da'i perlu mematangkan keilmuannya sehingga ia faham bagaimana mempraktikkan keilmuan tersebut dalam kehidupan sehari-hari. Seorang da’i perlu mengevaluasi setiap perkataan dan perbuatanya, apakah yang dikatakan tersebut sesuai dengan sumber aslinya dan apakah yang dilakukannya dalam perbuatan sehari-hari sesuai dengan petunjuk-petunjuknya. 
Nalar: Jurnal Peradaban dan Pemikiran Islam

Vol. 2, No. 2, Desember 2018

Gambar 2

Kompetensi Metode Dakwah Da’i

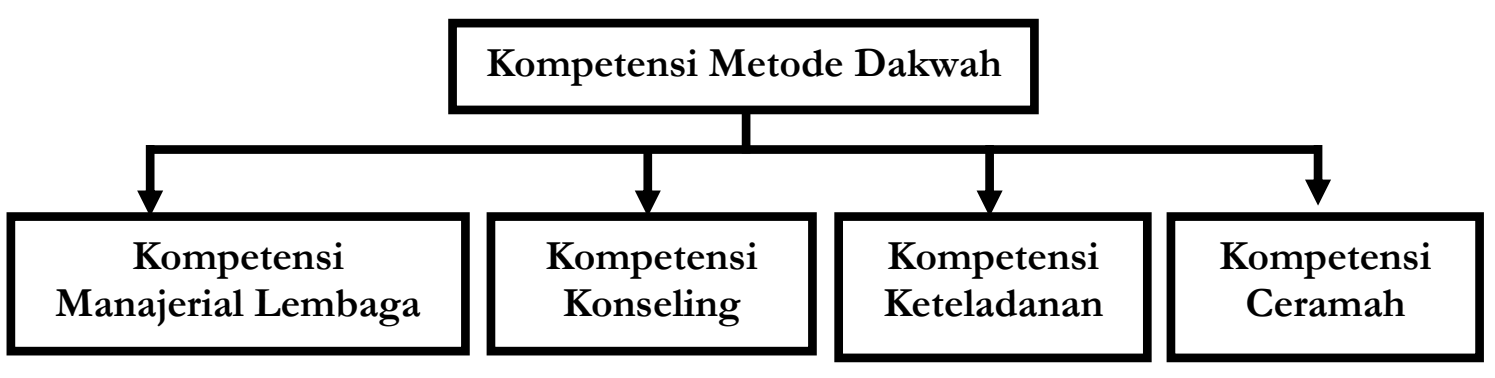

Kompetensi Da'i Terkait Materi Dakwah Pada Masyarakat Transmigran

Materi atau pesan dakwah adalah isi pesan, materi, ataupun segala syariat Islam sebagai kebenaran yang hakiki yang datang dari Allah Swt. melalui malaikat Jilbril disampaikan kepada Nabi Muhammad saw. yakni ada dalam Kitabullah alquran maupun Sunnah Rasul-Nya yang harus disampaikan oleh da'i (Subjek Dakwah) kepada mad'u (Objek Dakwah). Berdasarkan pemaparan hasil wawancara dengan para da'i terkait kompetensi materi di Dusun Cilodang dapat ditemukan bahwa kompetensi da'i terkait materi dakwah pada masyarakat transmigran meliputi penguasaan materi atau pesan dakwah, pemilihan materi dakwah sesuai kondisi dan penyusunan materi dakwah sebelum disampaikan kepada masyarakat.

Penguasaan materi atau pesan dakwah adalah hal pokok yang harus dilakukan oleh $d a^{\prime} i$. Penguasaan materi ini diperlukan agar da'i benar-benar menyampaikan sesuatu sesuai dengan sumber rujukannya. Da'i sangat tidak diperkenankan menyampaikan materi dakwah yang belum ia kuasai sepenuhnya. Hal ini untuk meminimalisir terjadinya kesalahan penyampaian kepada mad'u. Apabila terjadi kesalahan penyampaian materi tersebut bukan tidak mungkin akan menimbulkan kegaduhan dan merusak kredibilitas dari seorang da' $i$ itu sendiri.

Tuntutan bagi para däi untuk terlebih dahulu menguasai materi sebelum menyampaikanya banyak disinggung oleh banyak pakar ilmu dakwah. Menurut Ahmad Subandi (1994:68), salah satu syarat bagi da'i sebelum melakukan dakwah ialah pemahaman yang mendalam terkait ilmu atau materi dakwah. Kenyataan menunjukan sangat perlunya kesiapan ilmu sebelum beramal. Dengan adanya ilmu maka seorang muballigh akan mengetahui pula bagaimana berbuat untuk tercapainya tujuan itu.

Sedangkan menurut Ali Aziz (2012:217), secara ideal pendakwah adalah orang mukmin yang menjadikan Islam sebagai agamanya, alquran sebagai pedomannya, Rasulullah Muhammad saw. sebagai pemimpin dan teladan baginya. Prinsip tersebut benar-benar diamalkan dalam tingkah laku dan perjalanan hidupnya kemudian ia menyampaikan Islam yang meliputi akidah, syari'ah kepada seluruh manusia. Definisi ini menuntut pendakwah untuk mengamalkan ajaran Islam sebelum menyampaikanya kepada orang lain. Untuk bisa mengamalkan secara sempurna, pendakwah tentu harus memiliki penghayatan yang mendalam tentang ajaran Islam.

Keharusan seorang da'i terlebih dahulu menguasai materi dakwah kemudian mengamalkannya sebelum menyampaikan kepada mad'u adalah keharusan yang menjadikan seorang da'i itu ideal untuk berdakwah. Selain itu, penguasaan da'i terhadap materi dakwah turut memudahkan da'i dalam menjalankan tugas dan fungsinya sebagai penyampai ajaran Islam. 
Nalar: Jurnal Peradaban dan Pemikiran Islam

Vol. 2, No. 2, Desember 2018

Selanjutnya kompetensi berkaitan dengan materi dakwah adalah pemilihan dan penyusunan materi dakwah. Pemilihan dan penyusunan ini berkaitan dengan persiapan sebelum menyampaikanya. Selain itu, tujuan dari perlunya keahlian dalam memilih dan menyusun ini tidak lepas dari situasi dan kondisi masyarakat yang menjadi sasaran dakwah. Da'i perlu memperhatikan berbagai gejala-gejala yang ada dalam masyarakat kemudian menentukan materi yang seperti apa yang relevan dengan situasi tersebut.

Pemilihan dan penyusunan pesan dakwah sebelum disampaikan dapat pula dilihat dari pedoman dalam melakukan pidato. Menurut Rakhmat, hal yang perlu diperhatikan sebelum berpidato diantaranya yaitu memilih topik kemudian menyusun pesan yang akan di sampaikan. Sebelum memulai berpidato, muballigh harus mengetahui terlebih dahulu apa yang akan disampaikan dan tingkah laku apa yang di harapkan oleh khalayak. Topik sangat berperan penting dalam sebuah teks, semua topik diusahakan mempunyai daya tarik agar bisa menarik minat para pendengar. Topik berkaitan erat dengan judul pada pidato, jika topik adalah pokok hal yang akan diulas maka judul adalah nama bagi topik tersebut. Pengorganisasian pesan dapat dilihat dari pesan itu sendiri atau cara berpikir manusia. Pertama dapat disebut organisasi pesan (massage organitation) dan yang kedua adalah pengaturan pesan (massage arrangement).

Meskipun dalam beberapa literatur yang ada menempatkan bahwa pemilihan dan penyusunan materi terdapat dalam metode dakwah seperti dalam persiapan ceramah, namun hal tersebut tidak menjadi masalah. Materi dakwah sebagai salah satu unsur dakwah ia tidak berdiri sendiri, melainkan ia berdiri bersama dengan unsur lainya. Dalam artian antara unsur yang satu dengan unsur lainnya saling berkaitan menjadi satu kesatuan yang utuh.

Gambar 3

Kompetensi Materi Dakwah

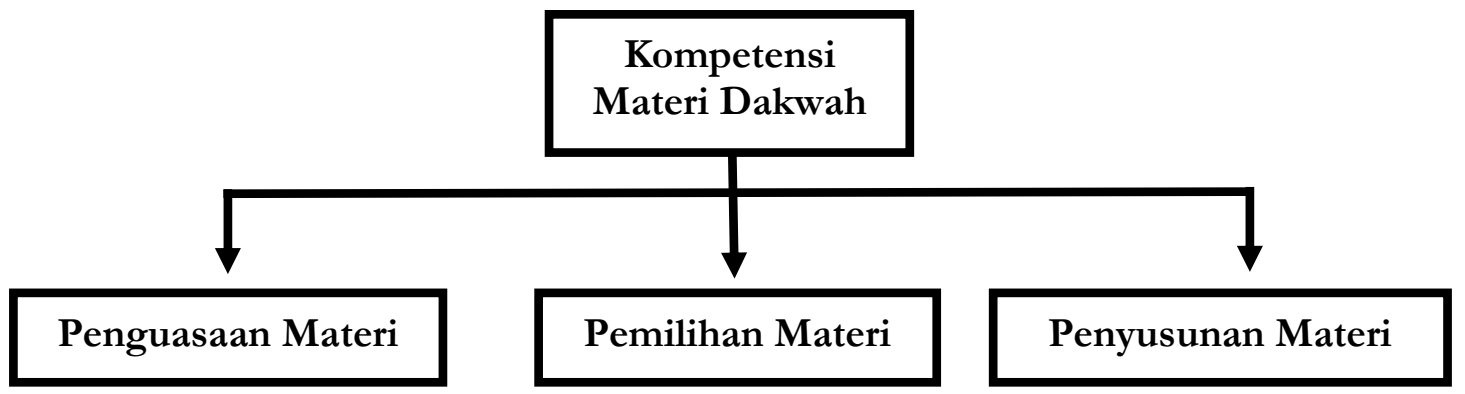

\section{Kompetensi Da'i Terkait Media Dakwah Pada Masyarakat Transmigran}

Media Dakwah adalah alat objektif yang menjadi saluran yang dapat menghubungkan ide dengan umat ataupun alat yang digunakan untuk menyampaikan materi dakwah (ajaran Islam) kepada mad'u. Sedangkan menurut Ibn Mandzur al-wasilah secara bahasa adalah merupakan bentuk jama dari kata al-wasalu dan al-wasailu yang berarti singgasana raja, drajat atau dekat. Sedangkan secara istilah adalah segala sesuatu yang bisa mendekatkan kepada sesuatu yang lain (Enjang AS, 2009:95).

Berdasarkan hasil wawancara dengan para dä $i$ di Dusun Cilodang didapatkan temuan bahwa kompetensi yang harus dimiliki oleh seorang da'i adalah kepekaan terhadap teknologi terbaru dan beradaptasi dengan berbagai media baru. Kepekaan tersebut diaplikasikan oleh da'i dengan mempelajari media-media baru tersebut. Sedangkan kemampuan beradaptasi diwujudkan dengan sikap bahwa kenyataan ilmu pengetahuan dan 
Nalar: Jurnal Peradaban dan Pemikiran Islam

Vol. 2, No. 2, Desember 2018

teknologi akan terus berkembang, maka seorang da'i perlu membiasakan dan mengikuti perkembangan tersebut dengan terbuka.

Era informasi ditandai oleh semakin banyaknya tenaga kerja, kian terarahnya pikiran ke dalam kegiatan yang berhubungan dengan teknologi informasi. Selain itu, era infomasi juga ditandai dengan semakin berperannya teknologi informasi dalam kegitan ekonomi, politik, ideologi dan budaya. Dampak yang ditimbulkannya adalah bahwa teknologi memberikan dampak yang baik bagi masyarakat, seperti dengan menggunakan televisi, komputer dan internet, maka dengan cepat dapat mengetahui perkembangan serta kejadian di Indonesia, bahkan seluruh dunia. Akan tetapi harus juga disadari sebab tidak sedikit pula dampak negatif yang ditimbulkan teknologi internet. Menurut Abdur Rahman (2013:141) hal tersebut dapat diamati dari penggunaan media elektronik seperti televisi dan internet melalui komputer dan lain sebagainya, yang justru merusak citra dan akhlak terutama dikalangan kawula muda bahkan merambah kepada anak-anak, yaitu dengan disiarkannya tayangan-tayangan pornografi dan pornoaksi yang tidak sesuai dengan Islam.

Kepekaan da'i terhadap kemajuan teknologi informasi harus ditandai dengan mempelajari setiap hal baru tersebut. pada tahapan implementasinya da'i harus bisa memanfaatkan setiap teknologi terbaru tersebut dalam menunjang kegiatan dakwah. Kebutuhan masyarakat akan teknologi informasi tersebut memperbesar peluang bagi da'i untuk menyisipkan pesan-pesan religius didalamnya. Sedangkan pada dampak positif yang ditimbulkan oleh kemajuan teknologi informasi tersebut, seorang da'i harus memposisikan diri sebagai pengingat bahkan pencegah dari dampak negatif teknologi tersebut.

Untuk dapat mencapai tujuan yang tepat dan mendapatkan keberhasilan, maka seorang da'i harus pandai dalam memilih media dakwah. Masyarakat masa kini adalah masyarakat plural yang berkembang dengan berbagai kebutuhan yang praktis, sehingga kecanggihan teknologi mau tidak mau akan menghadapi dan menjadi idaman dalam kehidupan masyarakat. Kecanggihan teknologi telah membuka sekat dan menghilangkan batas ruang dan waktu, sehingga memilih dan menggunakan media dakwah yang tepat sudah merupakan keharusan dan tuntutan zaman.

Bungin (2008:143) menyebutkan bahwa di era modern ini, perkembangan di bidang teknologi informasi sedemikian pesatnya sehingga kalau digambarkan secara grafis, kemajuan yang terjadi terlihat secara eksponensial dan tidak ada yang dapat menahan lajunya perkembangan teknologi informasi. Keniscayaan tersebut hanya bisa diimbangi dengan kesediaan para da'i mengikuti perkembangan tersebut dan mempelajarinya. Amat disayangkan manakala kemajuan teknologi informasi ini tidak dimanfaatkan untuk kepentingan dakwah. Apalagi dalam realitas sekarang ini, hampir sebagian besar masyarakat telah memiliki peralatan teknologi informasi, baik komputer, internet, handphone, dan sebagainya. Ibaratnya, dunia masyarakat sekarang ini adalah dunia teknologi informasi. Masyarakat akan dianggap "kuper" (kurang pergaulan) atau "gaptek" (gagap teknologi) apabila tidak mempunyai peralatan teknologi informasi. Dalam konteks ini kepekaan terhadap kemajuan teknologi informasi dan beradaptasi denganya adalah keahlian yang harus dimiliki oleh para da'i guna mengimbangi perkembangan zaman yang ada. Peran da'i yang sentral sebagai tulang punggung kehidupan beragama dirasa cukup menjadi alasan atas keharusan penguasaan teknologi tersebut. Selain itu, hal ini perlu dipersiapkan guna mengantisipasi kemunculan hal baru dalam teknologi informasi yang lebih mapan. Da'i dengan penguasaan teknologi informasi dan media baru dapat meningkatkan kredibilitas da'i pada masyarakat transmigran. 
Nalar: Jurnal Peradaban dan Pemikiran Islam

Vol. 2, No. 2, Desember 2018

Gambar 4

Kompetensi Media Dakwah

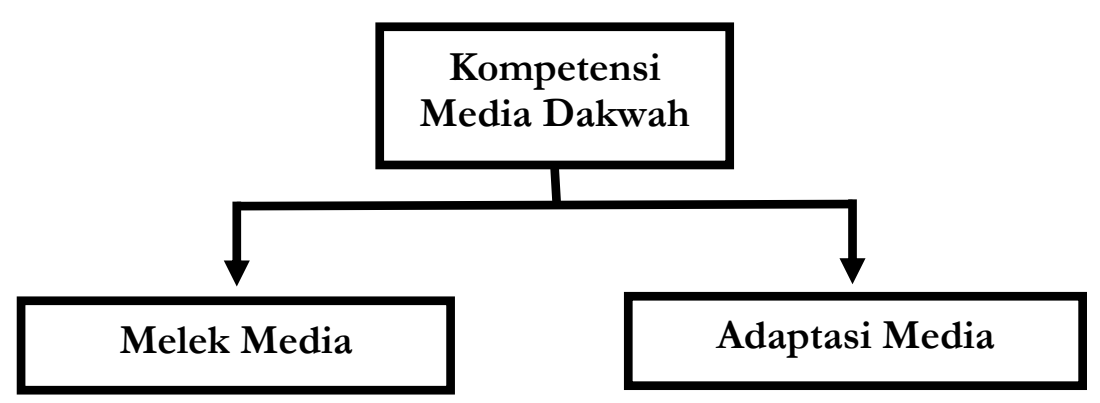

\section{Simpulan}

Berdasarkan analisis terhadap temuan di lapangan dapat disimpulkan bahwa dakwah pada masyarakat dengan tingkat keberagaman yang tinggi menuntut para da'i untuk memiliki keahlian dalam melihat situasi dan kondisi para mad'u. Pada tataran ini keberhasilan berdakwah pada masyarakat multietnis tidak hanya ditentukan oleh kompetensi da'i dalam memberikan ceramah dan tausiyah saja, namun kompetensi sosial budaya, manajerial dakwah, dan penguasaan media juga sangat diperlukan. Hal ini karena dakwah pada masyarakat multietnis yang terpenting adalah membumikan ajaran Islam dalam berbagai sendi kehidupan masyarakat baik dalam aspek akidah, syari'ah, maupun akhlak serta sosial budaya masyarakat. 
Nalar: Jurnal Peradaban dan Pemikiran Islam

Vol. 2, No. 2, Desember 2018

\section{DAFTAR PUSTAKA}

Amin, Samsul Munir. 2009. Ilmu Dakwah. Jakarta: Amzah.

Anshari, Endang Saifuddin. 2004. Wawasan Islam: Pokok-Pokok Pikiran Tentang Paradigma dan Sistem Islam. Jakarta: Gema Insani Press.

Aziz, M. Ali. 2012. Ilmu Dakwah. Jakarta: Kencana.

Bungin, Burhan. 2008. Sosiologi Komunikasi. Jakarta: Kencana.

Enjang AS dan Aliyudin. 2009. Dasar-dasar Ilmu Dakwah. Bandung, Widya Padjadjaran

Kamali, Mohammad Hashim. 2013. Membumikan Syari'ab: Pergulatan Mengaktualkan Islam. Bandung: Mizan.

Nasution, Harun. 1995. Islam Rasional: Gagasan dan Pemikiran Prof. Dr. Harun Nasution. Bandung: Mizan.

Rahman P, Abdur. 2013. "Teknologi Informasi sebagai Peluang dan Tantangan Dakwah" dalam Jurnal Al-Munzir, Vol. 6 No. 2 November 2013.

Rakhmawati, Rukhaeni Fitri. 2016. "Kaderisasi Dakwah melalui Pendidikan Islam” dalam Jurnal Tadbir Vol. 1 No. 1 Juni 2016

Ridwan, Aang. 2010. "Humor Dalam Tabligh: Sisipan Sarat Estetika" dalam Jurnal Ilmu Dakwah Vol. 4 No. 15 Januari-Juni 2010.

Sardjadidjadja, Rukman. 2008. Transmigrasi Pembaruan dan Integrasi Nasional. Jakarta: Pustaka Sinar Harapan.

Shihab, M. Quraish. 2004. Wawasan al-Qur'an: Tafsir Maudhi'i atas Berbagai Persoalan Umat. Bandung: Mizan.

Subandi, Ahmad. 1994. Ilmu Dakwah : Pengantar kearah Metodologi. Bandung: Syahida.

Tajiri, Hajir. 2015. Etika dan Estetika Dakwah. Bandung: Simbiosa Rekatama Media. 